\title{
Dynamics of the evolution of the strategic management concept: From the planning school to the neostrategic approach
}

\section{Tomasz Kafel ${ }^{1}$ iD, Bernard Ziębicki}

\begin{abstract}
Purpose: Strategic management has been developing in business theory and practice for over 50 years. Presently, it constitutes the main area of research interest in management science. The contemporary conditions of business operations create new challenges for strategic management, such as the use of dynamic capabilities in strategy building, relational strategies, networking of organizations, technology development and automation of processes, and global strategies. These challenges are often referred to as neostrategic management. The purpose of this publication is to present the findings of research concerning new strategic management concepts and challenges. Methodology: The main research method of this article was a narrative literature review. On the basis of the research, the development of the concepts as well as contemporary trends and challenges of strategic management were characterized. There is also a synthesis of the problems and research results presented in the articles in this special issue of JEMI. Findings: Various schools and approaches to strategy formulation have been created. They indicate different factors that allow for success in strategic management such as: setting long-term goals, selection of programs and their execution plans (planning school); connection of the enterprise with the environment (evolutionary school); focusing attention on competitive advantage and achieved performance (position-based school); focus on one's own resources and competences (resource school); use of opportunities and creating innovation (simple rules school); selection of the best option and orientation in business management (real options school); or eclectic perspectives, integrating the listed approaches. The strategic management concept has two dimensions. The first dimension is related to the emergence of subsequent, new strategic management

1 Tomasz Kafel, Ph.D., Hab., Associate Professor, Department of Organization and Management Methods, College of Management and Quality Sciences, Cracow University of Economics, Rakowicka 27, 31-510 Kraków, Poland, e-mail: kafelt@uek.krakow.pl (corresponding author), (ORCID: https://orcid.org/0000-0003-2931-1921).

2 Bernard Ziębicki, Ph.D., Hab., Associate Professor, Department of Organization and Management Methods, College of Management and Quality Sciences, Cracow University of Economics, Rakowicka 27, 31-510 Kraków, Poland, e-mail: ziebicki@uek.krakow.pl (ORCID: https://orcid.org/0000-0003-3628-8264).
\end{abstract}


concepts, which often hark back to the previous schools and approaches. The second dimension of development applies to operationalization and adjustment of the previous concepts to the changing conditions. Implications for theory and practice: The paper characterizes the research results presented in the articles included in this JEMI issue. They deal with various problems and challenges in the field of strategic management, such as the relationship between market dynamics, market orientation and performance of enterprises; the innovativeness of companies as a contemporary strategic orientation of companies; the strategy implementation and the management of the organization change; problems of strategic management of the development of the city. Originality and value: The problems presented in the study relate to challenges and new concepts in strategic management. They enrich the existing knowledge on the development of strategic management, and also create inspiration for further research in this area.

Keywords: evolution of the strategic management concept, neostrategic management, strategy implementation success, market dynamism, strategic management of cities, innovation strategy.

\section{INTRODUCTION}

The beginning of the 21st century brought about fundamental changes in the conditions of business operations. They are above all a consequence of the political processes (particularly military conflicts), social processes (in particular migration), economic (particularly the growing disparity of income), technological ones (particularly the effects of the so-called Fourth Industrial Revolution) and the phenomena forming health threats (in particular the COVID-19 pandemic). The unpredictability of the organization's environment is not a phenomenon we have only been dealing with in recent years. For this reason, among others, traditional strategic planning methods became outdated as early as the 1990s (Vrdoljak-Raguž, Jelenc, \& Podrug, 2016; Kaleta $\&$ Wittek-Crabb, 2016). As a consequence, other research areas in strategic management have been developed, among others: strategic alliances, mergers and acquisitions, internationalization strategies, or strategic learning (Vrdoljak-Raguž, Jelenc, \& Podrug, 2016). Certainly, the increased uncertainty of the conditions of business operations can be noticed at present. For this reason, new concepts, models, and methods presently arise, aspiring to be modern tools for studying the strategic management "blackbox." They go away from the classical understanding of strategic management, towards designing the practice, process and approaches to strategy on the basis of the achievements of other scientific fields. This combination of various perspectives and approaches to strategic management, along with the application of knowledge from other disciplines, is what distinguishes new strategic management, for which the international literature uses the 
term: neostrategic management. The purpose of this article is to present a relatively little-known approach to strategic management and especially to indicate new research directions undertaken in the field of strategic management. In the first part of the article, the authors characterize the most important, in their opinion, challenges faced at present by enterprises and their consequences for the strategic management process. Some directions of research in strategic management will also be proposed here, resulting from the challenges being described. Further, the evolution of strategic management schools and the essence of the new strategic management concept (neostrategic management) and the disciplines that create it will be presented. Finally, the articles presented in this issue, with the contents matching the new strategic management concept, will be summarized. The further directions of strategic management concept exploration, hopefully creating inspiration for other researchers and management practitioners, will be indicated at the end of the paper.

\section{LITERATURE BACKGROUND}

\section{Key changes in the environment of enterprises and their consequences for the strategic management process}

New challenges faced by entrepreneurs at the beginning of the 21st century have significant consequences for the approach to the strategic management process. Among those challenges, the most important ones are mainly the effects of the recent industrial revolutions (both the third, but particularly the fourth and the fifth one) that are difficult to anticipate as well as the pandemic phenomena. As a consequence, the uncertainty of business operations is growing. Other essential processes that managers must tackle include pressure on corporate social responsibility, the increasing potential of emerging markets, and shrinking natural resources. It seems that the main problem for the "strategic management" discipline will be the fast pace of change and the scale of novelties concerning enterprises and their environment. The period of intensive economic and technological change started at the end of the 20th century, known as the Third Industrial Revolution, shows its new face, which has already been named the Fourth Industrial Revolution. This idea, for which the term Industry 4.0 is used, assumes that manufacturing competitiveness can be ensured based on new technologies combined with the Internet (the so-called business networking). Here, we are talking about the realization of the idea of a smart factory through the application of technologies and principles of organization of the value chain 
together using and utilizing cyber-physical systems, the Internet of Things (intelligent mobility) and cloud processing (Hermann, Pentek, \& Otto, 2015; Kagermann, Wahlster, \& Helbig, 2013). Other equally important elements of the Fourth Industrial Revolution are the internet of persons (social and business networks), internet of services (smart networks and logistics), and internet of data (smart buildings and apartments). Some researchers include smart factories arising on the basis of the mentioned technologies as phenomena of the Fifth Industrial Revolution (Furmanek, 2018). The reality of the Fifth Industrial Revolution implies that in the near future, chat-bots and cobots (collaborative robots) will substitute live people in performing many work processes, while blockchain and cryptocurrencies will completely change the functioning of the world of finance. In the opinion of Furmanek (2018), the introduction of artificial intelligence and self-learning machines changes the way decisions are made and communication is conducted, and this process is irreversible and will proceed. It is therefore difficult to imagine that these phenomena be neglected in the business strategic management process. Given the key challenges of the contemporary times described above, and in particular the future, the authors have made an attempt to determine the directions of future research in strategic management, which is synthetically presented in Table 1.

The development of research in the field of strategic management within the last two decades has been dramatic. The survey areas described in the table are already the subject of scientists work around the world. For example, Sanchez, and Heene (2004) described the new strategic management in the context of competition and competence. ZakrzewskaBielawska (2021) revealed the essence and meaning of the ambidextrous strategy concept, in turn, Kosch and Szarucki (2020a, 2020b) indicated a trend of growing international scientific collaboration in the field of strategic management. When analyzing the literature on the subject, it can be noticed that the current field of strategic management is strongly theory based, with substantial empirical research. This trend is also followed by the approach described below, for which the term neostrategic management was adopted. 
Table 1. Directions of research in strategic management in view of the crucial challenges of the contemporary times

\section{CHALLENGES OF THE CONTEMPORARY TIMES}

Subsequent industrial revolutions (including so-called „blue swans," characterizing unexpected events generated by digital technologies and artificial intelligence)

\section{CONSEQUENCES FOR THE STRATEGIC MANAGEMENT PROCESS}

- Change in sources of competitive advantage towards knowledge management. sectors (e.g., photography and mobile phones).

- Hypercompetition - quick and turbulent competitive actions (faster erosion of competitive advantage) forcing companies to ensure continuous innovation.

- Shortened life cycle of sector/ product/service.

- Development of virtual businesses.

- Intensifying the diversification strategy (radical increase in the quality level of the offered products).

- Value migration from old to new sectors.
- Blurred boundaries between

FUTURE RESEARCH AREAS

- Identification of future conditions of business operations.

- Indication of the sources of market agility and their determinants in the future.

- Application of inventive methods to determine the directions of change/ modification of the operational domain (disappearing sectors).

- Broader application of cooperation strategies with regard to scientific and development works.

- Preparation of new ways of information support for strategic management.

- Identification of areas of work outside the office/company.

- Development/modification of the „learning organization”.

- Designing future business models (for instance, taking account of business value as the strategic goal).

Strategic uncertainty (resulting, among others, from the phenomena described by Nassim Taleb as „black swans" or new pandemics)
- Need to make sustainable choices under the conditions of extreme uncertainty leads to the "strategy paradox." ${ }^{3}$

- Business strategy starts resembling a set of options ${ }^{4}$, which can be either realized or discarded.

- Change in approach to risk: "failure management" instead of risk minimization.

- Utilization of the so-called "smart defeats."

- Prediction according to the VUCA model (volatility, uncertainty, complexity; ambiguity).
- Development of methodologies, improvement of forecasting techniques and algorithms.

- Deepening and disseminating knowledge about the real options school.

- Improvement of methods of successful strategy implementation in the conditions of continuous uncertainty.

- Development of mental/cognitive models used to anticipate changes in the environment (the so-called "dominating logic").

- Popularization of the concept of loose resources (using the metaphor of organism).

- Antifragility (Hydra) as the antidotum to the so-called „black swans” (Taleb 2007, 2012)

3 It consists, in the opinion of Raynor, in the fact that „actions and characteristics necessary to achieve spectacular success at the same time increase the risk of total failure" if we hold tight to the perfectly prepared strategy, not accepting any changes during its implementation (Raynor, 2008).

4 This option is the right to take a specific action in the future on the principle if-then giving the company freedom to postpone the decision until relevant information is obtained in the future (Wąsowska, 2012).

5 This refers to making mistakes in an 'as-least-costly way as possible' by detecting errors, correcting them, learning from them, and building resistance for the future [ibidem]. 


\begin{tabular}{|c|c|c|}
\hline $\begin{array}{l}\text { CHALLENGES OF THE } \\
\text { CONTEMPORARY } \\
\text { TIMES }\end{array}$ & $\begin{array}{l}\text { CONSEQUENCES FOR THE } \\
\text { STRATEGIC MANAGEMENT } \\
\text { PROCESS }\end{array}$ & FUTURE RESEARCH AREAS \\
\hline $\begin{array}{l}\text { Pressure on business } \\
\text { responsibility } \\
\text { (including change in } \\
\text { the approach to the } \\
\text { employee). }\end{array}$ & $\begin{array}{l}\text { - Redefinition of mission of } \\
\text { the organization (dilemma: } \\
\text { responsibility versus } \\
\text { profitability). } \\
\text { - Strategic model of corporate } \\
\text { social responsibility as a source } \\
\text { of competitive advantage (e.g. } \\
\text { Toyota Prius). } \\
\text { - Responsive model of corporate } \\
\text { social responsibility as a tool for } \\
\text { improving the image. } \\
\text { - Standardization of CSR activities } \\
\text { and formation of stock exchange } \\
\text { indexes (CSR's effect on business } \\
\text { value). } \\
\text { - Dilemma - image or competitive } \\
\text { advantage (or perhaps image } \\
\text { and competitive advantage?). } \\
\end{array}$ & $\begin{array}{l}\text { - Improvement of business cooperation } \\
\text { models with non-governmental } \\
\text { organizations and public institutions. } \\
\text { - Development of methods for building } \\
\text { long-term bonds of the company } \\
\text { (owners, management) with the } \\
\text { employees. } \\
\text { - Development of a model of shared } \\
\text { (management and employees) } \\
\text { accountability for effective operations } \\
\text { of the company (e.g., using the } \\
\text { employee share ownership concept). } \\
\text { - Implementation of the assumptions for } \\
\text { full participation in management. } \\
\text { - Solutions in the sphere of employee } \\
\text { privacy protection. } \\
\text { - Dissemination of the business } \\
\text { ecosystem concept. }\end{array}$ \\
\hline $\begin{array}{l}\text { Potential of emerging } \\
\text { markets (including } \\
\text { demographic } \\
\text { explosions) }\end{array}$ & $\begin{array}{l}\text { - Scale effect - emerging markets } \\
\text { account for } 70 \% \text { of the future } \\
\text { growth of Western international } \\
\text { corporations (including China } \\
\text { and India being } 40 \%) \text {. } \\
\text { - Acute competition for } \\
\text { customers from the highest } \\
\text { (by income) market segments } \\
\text { - here approx. } 20000 \\
\text { international companies are } \\
\text { present on the emerging } \\
\text { markets. } \\
\text { - Unused potential of segments } \\
\text { from the so-called "bottom of } \\
\text { the income pyramid" on the } \\
\text { emerging markets. }\end{array}$ & $\begin{array}{l}\text { - Development of market segmentation } \\
\text { methods with focus on examination of } \\
\text { the so-called "bottom of the income } \\
\text { pyramid." } \\
\text { - Professionalization of researching } \\
\text { social and cultural differences. } \\
\text { - Identification of communication } \\
\text { channels and distribution channels } \\
\text { integrated with the segment from the } \\
\text { bottom of the pyramid. } \\
\text { - Preparation of models of cooperation } \\
\text { with NGOs in order to reach out to } \\
\text { the segments from the bottom of the } \\
\text { pyramid. }\end{array}$ \\
\hline $\begin{array}{l}\text { Shrinking natural } \\
\text { resources (including } \\
\text { so-called „green } \\
\text { swans” symbolizing } \\
\text { catastrophic } \\
\text { ecological events) }\end{array}$ & $\begin{array}{l}\text { - Competitive fight enriched with } \\
\text { high tech dimension. } \\
\text { - New energy sources as } \\
\text { foundations of competitive } \\
\text { advantage. }\end{array}$ & $\begin{array}{l}\text { - Development of a developed } \\
\text { cooperation system in economic } \\
\text { macrosystems (e.g. common policy of } \\
\text { purchasing raw materials on the level } \\
\text { of the whole European Union). } \\
\text { - Working on organizational } \\
\text { transformation strategies (alliances, } \\
\text { mergers of large business unions, } \\
\text { virtual systems). }\end{array}$ \\
\hline
\end{tabular}

Source: Authors' own study on the basis of Banaszyk and Urbanowska-Sojkin (2007); Romanowska (2004); Roland Berger Strategy Consultants (2011); Stabryła (2000); Szczerski (2012); Taleb (2007, 2012); Walas (2007); Wąsowska (2012).

\section{Development of strategic management concepts towards the neostrategic approach}

The challenges of the contemporary times presented in Table 1 contribute to the fact that strategic management is subject to constant changes, like the whole discipline of management sciences. New theories, concepts, methods, 
and techniques aimed at improving the management of both commercial and non-commercial organizations are being created almost each year. This is a consequence of departing from the simplified and naive claim of the precursors of scientific management (in particular the engineering school) that there is one best management method. At the end of the 20th century, a number of new approaches leading to the so-called Organizational Excellence appeared. Among them, there are, for example, the concept of a New Wave in Management, Process Management, Business Process Reengineering, TQM, Project Management, and Postmodernism in Management. Among the newest achievements in management sciences - known in the United States and Europe - certainly include, for instance, The Actor-Network Theory, The Organization Learning Theory, The Positive Organizational Management Concept, The Organization's Social Responsibility Concept (considering the environmental context of management), The Creative Class Concept, the birth of the so-called Social Entrepreneurship (in particular among nongovernmental organizations), and, in the case of public institutions, New Public Management and Governance Concept or the so-called Neoweberism. Their formation and dissemination is a result of a continuous search for instruments to improve the effectiveness of companies (in particular their profits) in the new operating conditions. On the other hand, in the public and non-governmental sector, new management concepts or methods are largely a result of isomorphic pressures arising directly from the goals expected from these organizations (what often means transformation of the solutions applied in business to non-commercial organizations). These changes also relate to strategic management, which is a separate part of management sciences. According to Romanowska and Krupski (2010), its development takes place both at the level of developing theoretical models and the methods supporting strategic management (in particular strategic analysis methods) and verification of theoretical models in management practice. Research objects are mainly businesses, but the majority of theories and tools are also applied in public institutions and non-governmental organizations.

Multiple theoreticalviews and practicalexperiences ofadvisorycompanies and enterprises on the development of strategic management have created the need to order them. The consequence of this is various classifications of strategic management schools. The roots of strategic management have been in a more applied area, often referred to as business policy (Hoskisson et al., 1999). An effect of changes in the business environment was the management practitioners' search for theories and methods of solving the problems they were facing. In response to the needs of the management practice in the second half of the 20th century, subsequent strategic management theories, models, and methods were born. The convergence 
of the views presented by both management practitioners and theoreticians on the methods of solving organizational problems allowed, in subsequent periods, the separation of the so-called strategic management schools or streams, which most frequently stress one of the basic strategic management categories, for example: plan, competitive environment, resources, building around it a philosophy of the contemporary problem-solving for the future of the organization (Krupski, 2010). According to Krupski (2010), regardless of the priority dilemma: markets or resources?, subsequent schools also reach for large theories describing the reality such as, for example, the general systems theory, the complexity theory, the chaos theory, the game theory, and the options theory, in search of any patterns therein to describe problems, or even patterns for solving them. The growing turbulence of the environment and the ineffectiveness of the proposed action patterns ensure continuous evolution of the schools, streams, and approaches to strategic management. They have been characterized and compared in numerous publications (e.g., Jelenc, 2009; Jelenc, 2007; Furrer, Thomas, \& Goussevskaia, 2008). In the 1950s and 1960s the main challenge faced by managers was the problem of coordinating and controlling their increasingly complex companies. The emphasis on long-term planning required the integration of strategic and financial management.

The answer to these problems from the planning school of strategic management created in this period was the document containing the plan, usually a several-year one, presenting the company's goals and tasks, priorities for particular products and businesses where the company operates, and allocating the resources for investment (Obłój, 2007). This approach assumed that the environment is relatively stable, controllable or at least predictable (Mintzberg \& Waters, 1985; Wąsowska, 2012). Excessive formalization and stiffening of the planning process, a focus on procedures, failure to notice conflicts of interests of various groups in the company, slow response to changes in the environment, all contributed to the broad criticism of the planning school and the establishment of the so-called evolutionary school of strategic management. The representatives of this stream adopted the opinion that each enterprise has the capacity of learning and improving, and strategy is an expression of an accord among the process participants, rather than a document developed by external specialists and imposed on the management board (Romanowska, 2004). In the subsequent years (the turn of the 1960s and 1970s), planning in large companies involved the diversification process. Ansoff (1965) believed that strategic decisions are rather concerned with external than internal problems of the company, particularly related to the choice of the products that the company will produce and the markets will sell them on. Unfortunately, in the 1970s, the oil 
crisis, excessive diversification as well as aggravating competition from Asian (mostly Japanese and Korean) companies changed the method of making decisions in enterprises, leading to autonomization of thinking about strategy (Grant, 2005). It was decided that the company's performance depends, first of all, on its (competitive) position in the environment, and strategy is to contribute to building competitive advantage. Porter (2001), the co-creator of the position-based strategic management school emerging in the 1980s, relied on the industrial organization stream in search of industry-based profitability determinants.

The 1990s are the birth of an important stream in research on strategy, the so-called resources and competences school, which treats strategy as a method of resource allocation, letting the company maintain or improve performance (Barney, 1991). Here, strategy is to respond to a completely different (as compared to the position-based school) question, which is "What should we be?" (Romanowska, 2004). The concept of organizational capabilities (organizational capability) developed the "static" version of this approach, paying attention to the ability to identify and use opportunities and threats as well as the ability to maintain competitive advantage by building, combining, protecting and reconfiguring resources (Teece, 2007). The beginning of the 21st century gave birth to subsequent schools and a completely different approach to strategy. Special attention should be paid to the simple rules school (how-to-rules, boundary rules, priority rules, timing rules), the representatives of which (e.g., Christensen) believed that the goal of strategy should be to find the answer to the question: "How should we act?" in the conditions of fast transformations in the environment and extreme uncertainties concerning market expectations, typical of the early 21st century. This school refers to the achievements of chaos theory, psychology, and biology. According to the supporters of this school, the essence of building competitive advantage is the ability to take advantage of occasional opportunities, building innovative strategies (Eisenhardt \& Sull, 2001). And, finally, one of the contemporary strategic management schools, real options school, is the result of borrowings from the theory of options and finance. Its representatives make the assumption that the huge uncertainty of the environment eliminates any sense in pursuing any long-term projects and ventures. Strategies should be treated as gradually climbing up the stairs having at all times the possible option to resign from further climbing (Domański, 2010).

It is worth noting that the newest strategic management solutions seem to go towards examining the so-called strategic dynamic. The primary representatives of this stream are D'Aveni, Ghemawat, Brandenburger and Nalebuff, Stacey, Brown and Eisenhard, von Krogh, Schwartz and Trgigeorgis 
(Segal-Horn, 2004). To some extent, De Witt and Meyer (2007) reference this stream and claim that, to succeed, businesses must manage contradictions, often reconciling and pursuing contradictory goals. Through a dialectical process, they should aim at balancing both exploratory and operating actions. In the opinion of Zakrzewska-Bielawska (2021), the term "ambidexterity" has been adopted for such abilities in the professional literature. This implies the need for contemporary companies to explore simultaneously new opportunities, to ensure profits in the future, and to use any present competences for current profitability. Both activities are necessary to achieve competitive advantage in the long term (Zakrzewska-Bielawska, 2021). In the opinion of the authors, this approach is consistent with the main idea behind the portfolio analysis, the aim of which is such allocation of measures that ensures the company's sustainable development. This often implies the concurrent use of both the diversification strategy (namely exploratory actions) and the penetration strategy (namely operating actions).

Some similarities can be noticed in presented schools or concepts of strategic management, being an obvious consequence of (the authors) noticing similar reactions or actions taken by entrepreneurs in reply to the problems they are forced to face at a specific time. However, the emphasis on different processes and problems can be noticed within each of the approaches, resulting in all of them having their enthusiasts today. Therefore, we can assume, after Stabryła (2000), that from the practical point of view, all (schools) together form a mutually complementing whole, and consequently, the complex nature of the research approach will be one of the main characteristics of the developed strategic management concept. The development of strategic management concepts is still progressing. It has two dimensions. The first of the dimensions is related to the emergence of subsequent, new strategic management concepts, which often hark back to the previous schools and approaches. The second dimension of development applies to the operationalization and adjustment of the previous concepts to the changing conditions. These changes have specific consequences, both for the strategic management process and the future research areas related to the strategic management concept. The above-described contemporary conditions of business operations create new challenges for strategic management. These include, for instance, the use of dynamic capabilities in strategy building (Segal-Horn, 2004; Teece, 2007; Krzakiewicz \& Cyfert, 2014), relational strategies (Zakrzewska-Bielawska, 2017), networking of organizations (Krzakiewicz \& Cyfert, 2013; Czakon, 2016), technology development and automation of processes (Schwab, 2016), global strategies (Porter, 1986; Gupta, Govindarajan, \& Wang, 2008). In view of these challenges, some researchers postulate the assumption of a new 
term: neostrategic management (Vrdoljak-Raguž, Jelenc, \& Podrug, 2016). According to their assumptions, the key disciplines shaping neostrategic management are strategic entrepreneurship, spiritual management, behavior strategy and cognition, and strategy as practice. Among the disciplines shaping neostrategic management, the authors of the term have also identified supplementary disciplines, such as entrepreneurship, cognitive and social psychology, spiritual and religion movements, sociology, and anthropology (Vrdoljak-Raguž, Jelenc, \& Podrug, 2016). In the proposed neostrategic management concept, its creators have addressed an important and valid problem of adjusting the strategic management concept to the new economic conditions of the 21st century. In this concept, particularly valuable is its link to the problems faced at present by the strategic management concept and indication of the proposals to solve these problems. These solutions oscillate around such areas as networking the organizations, a multidisciplinary approach to strategic management, continuous improvement of strategy (in accordance with the idea of a learning organization), the enterprising nature of strategic thinking, and strategic group leadership (Vrdoljak-Raguž, Jelenc, \& Podrug, 2016; McGrath 2013).

\section{CONTRIBUTIONS}

The authors of the articles presented in this special issue of JEMI address problems and challenges that refer to the contemporary approaches of the strategic management concept, including the neostrategic management. The collection of articles in this issue shows how diverse the research areas in which the concept of strategic management is applied may be. Readers are concerned with such areas as: the company's market orientation in strategic management and its effect on the financial performance in the context of market dynamics; innovation as the contemporary strategic orientation of companies; or strategy implementation and change management, from the point of view of the differences in the perception of these processes by employees at various levels in the organizational hierarchy. The problem area of strategic management in the public sector has also been addressed. In this regard, the subject matter of the analysis was economic development strategy implementation processes at the level of municipalities and regions. All the articles present findings of empirical research, conducted with the use of both qualitative and quantitative research methods.

The article by Anna Wójcik-Karpacz, Jarosław Karpacz, and Joanna Rudawska addresses the relationship between market dynamics, market orientation, and performance of MSMEs. The research was conducted in 
Polish companies operating in technology parks. Two quantitative empirical research methods: CAWI and PAPI were used in the study. The research hypothesis was: Market dynamism moderates the market orientation - firm performance relationship; the positive effect of market orientation on firm performance is likely to be stronger under high market dynamism than under low market dynamism. The conducted research confirmed the assumed hypothesis. The surveyed companies were characterized by quite a considerable market orientation. Simultaneously, high values of standard deviations of different market orientation dimensions proved a significant differentiation in this regard. In addition, the identified levels of different market dynamics dimensions indicated that these companies were generally operating on a stable or moderately dynamic market. Under these conditions, a more often adopted strategic orientation was exploratory development rather than operating market exploration. Simultaneously, enterprises that exhibited a high market orientation achieved better financial performance than the competitors. Based on completed studies, a conclusion can be formulated about the significant role of market orientation in strategic management of MSME enterprises, regardless of the dynamics of the market they operate on.

The article by Edyta Bielińska-Dusza and Monika Hamerska addresses the problem of innovativeness of companies as a contemporary strategic orientation of companies (Block, Fisch, \& van Praag, 2017). The authors prove that strategic innovation, being a long-term process subjected to penetration of various types of innovation with strategic thinking, can be an effective management tool to achieve high operational effectiveness and maintain competitive advantage in the market. However, the level of innovativeness of companies is significantly diverse. Considerable differences in this regard are observed even within the same industry. The problem area of innovativeness of companies has been addressed in many scientific works. However, they have been concerned with particular companies, sectors, industries, and regions. On the other hand, there is no study showing the similarity of industries and their division into homogeneous groups in terms of the share of innovative companies. This gap became an inspiration for the research, the results of which are presented in the paper. This research aimed to classify the industries classified by PKD (NACE) divisions into homogeneous groups according to innovative projects of companies in the given industry. The completed research led to a number of interesting conclusions and observations. Companies from a particular industry can be divided into several innovation clusters, characterized by a high level of similarity of the innovation processes. This type of classification may increase the effectiveness of forecasting changes within the companies classified into 
the same cluster. The research also confirmed a high correlation between product and process innovations.

The article by Valentina Ivančić, Lara Jelenc, and Ivan Mencer addresses the problem of strategy implementation. Previous research concerning the problem area of strategy implementation focused mostly on the perspective of the top management, ignoring the assessment of this process by lower hierarchical levels (Simons, 2013). The hypothesis of the study was: There is a statistically significant difference in the evaluation of key implementation factors between employees from different hierarchical levels. The strategy implementation process was subjected to assessment with regard to four factors: people, allocation of resources, communication, operational planning, and control (Okumus, 2003). The study covered all large enterprises in Croatia. The applied research method was a survey of opinions on the basis of a questionnaire. A total of 208 questionnaires were sent back from 78 companies. The assumed hypothesis was confirmed. The study proved that the assessment of key strategy implementation factors significantly differs between the hierarchical levels in two out of four factors: communication and planning, and operational control. First line managers and operators most frequently expressed the opinion that strategy implementation instructions are unclear and that their suggestions are not taken into consideration. They also believe that communication-related to the strategy implementation process is usually too slow, resulting in a mess and reducing the effectiveness in coordinating operating tasks and introducing potential changes. On the other hand, when it comes to the perception regarding these factors - people and resource allocation - the study has not confirmed any significant differences between the different levels in the organizational hierarchy. The studies described have allowed the identification of different problems related to strategy implementation and, as a result, a number of recommendations have been formulated. First of all, top managers should take account of feedback from lower-level managers and operators, to identify any threats associated with strategy implementation. Operational problems that may occur, such as unclear or slow communication, budgeting discrepancies, incorrectly determined schedule of actions and its dynamic as well as improper ways of measuring performance when implementing strategy, can be significantly restricted thanks to these activities.

The issue of strategic change management was also discussed in the article by Ekaterina Brandtner and Jörg Freiling. It concerns the role of the dominant logic of the organization in change implementation. The authors raised two research questions: (RQ1) How to re-conceptualize the construct of the dominant logic to address both the driving and the hampering role in case of explorative turns? (RQ2) Which factors restrain and which factors allow 
explorative turns? The area of research was traditional German companies from the energy industry, characterized by a stable, well-established position. The authors of the article perceive the dominant logic of the organization, on the one hand, as a limiting factor for change implementation, and on the other hand, as a favorable factor that facilitates its interpretation. The research was qualitative. The results of the research confirm the positive influence of the dominant logic under the conditions of change. The data indicate that an exploratory turn, driven by dominant logic, works better with combined learning and unlearning abilities, an ambidextrous balance of exploration and exploitation, coexisting logic, the continuous adaptation of dominant logic, and lower levels of leadership strength and formal structures. However, the management of the organization plays a key role in interpreting the dominant logic. The response to the raised research question (RQ1) pointed to six factors: A) business success in the past; (B) core competence dependence; (C) structural rigidity and cost trap; (D) knowledge potential and learning capability; (E) risk aversion and complexity reduction; (F) communication and information behavior. Regarding the research question (RQ2), the four process mechanisms of unlearning, exploring, changing, and managing were identified. The research also confirmed the key role of the management of the organization in interpreting the dominant logic.

The special issue also includes an article devoted to the problem area of strategic management in the public sector by Jan Fazlagić, Aleksandra Szulczewska-Remi, and Windham Loopesko, relates to the problem area of the role of the entrepreneurship promotion policy in the strategic management of a city. The article presents the findings of a comparative analysis of regional development policies in Poland and Germany. The main research question of the article was: $(R Q)$ How do urban policies in Poland supporting knowledge spillovers and entrepreneurship - the key drivers of regions' innovative capacity development to sustain global competitiveness - differ from German cities' policies? Strategic documents of the largest Polish and German cities and partially structured interviews were used in the study to answer the so formulated question. The completed research proved that Polish and German cities apply many of the same approaches to knowledge-transfer support policies. Both groups regard entrepreneurship as an important element of the development strategy. However, German lands support such activities to a greater extent as compared to Polish voivodeships. This mostly results from a stronger position and a higher autonomy of the lands in the federal structure of Germany as compared to voivodeships in Poland, which operate within a more uniform system. Polish cities are much more dependent on implementing their economic growth strategies on EU funds compared to German cities. Industrial cluster promotion policy is important in both city 
groups. However, in Germany, such policies were already implemented much earlier and are presently well established. The majority of the respondents from Poland believe that their cities should put a greater emphasis on creating industrial clusters. Polish and German cities offer many initiatives attracting private capital, but in both cases, the main challenge is strengthening the social perception of entrepreneurship, especially among young inhabitants. Factors contributing to the development of entrepreneurship are tax reliefs and financial incentives. As it results from the studies performed, such incentives play a greater role in Poland than in Germany. However, neither German nor Polish cities guarantee significant incentives or preferences for companies operated by young people. The research also indicated the significant role of universities in supporting entrepreneurial operations. In this regard, the activity of universities and cooperation with local governments is more considerable in German than in Polish cities. Also, social entrepreneurship is a more developed concept in German cities as compared to Poland, but is becoming more important in both groups.

\section{Further research}

The presented problems and research findings involve different problems related to development and implementation of strategic management in contemporary enterprises and non-profit organizations. They enrich the present knowledge in this area and indicate further exploration directions, creating inspiration for other researchers and management practitioners. Strategic management is a branch of management science that is constantly being developed. Changes in the environment of enterprises create new challenges in this area and contribute to the creation of new concepts of strategic management. Classic methods are also perfected to increase their effectiveness. This special issue of JEMI presents selected current problems in the development of strategic management concerning both: the development of known concepts and methods of strategic management, as well as new ones. Much attention was paid to the implementation of strategic management. The conducted research provided new knowledge in the areas of the discussed problems but also allowed to set the directions for further research.

In the article by Anna Wójcik-Karpacz, Jarosław Karpacz, and Joanna Rudawska, comparative research on the interrelationships between different strategic orientations and company results in many contexts was indicated as the direction of further research. In particular, these studies should cover companies that introduce current products into new markets, new products into existing markets, and new products into new markets. The importance of these issues for strategic management grows along with the progress of the 
managerial staff in increasing the effectiveness of business organizations. The research conducted by the authors of the article concerned MSME enterprises operating in technology parks. However, the issue of the impact of strategic orientations on financial results is general and concerns enterprises of all categories. Therefore, this research should be extended to other types of enterprises and carried out internationally.

The result of Edyta Bielińska-Dusza and Monika Hamerska's research is to divide industries, classified according to NACE divisions, into groups that will be homogeneous in terms of the share of innovative enterprises in a given industry. Although the research procedure showed which enterprises belong to the groups of PKD divisions, it does not provide sufficient ground for inferring causation. It can be assumed that the similarity of the group may result from the amount of financial outlays, knowledge of products and services, use and level of support with IT tools, or extensive interorganizational cooperation. These studies can be a starting point for further in-depth analysis. An attempt to create a ranking of industries in terms of the share of innovative enterprises introducing new or improved products or business processes and checking whether it will reflect clusters of homogeneous industries seems to be an interesting research direction.

Extending the research to companies of different sizes and belonging to different industries is also indicated by Valentina Ivančić, Lara Jelenc, and Ivan Mencer as the direction of future research. The research presented in their article concerns the issues of strategy implementation and the role of operational employees in this process. The problem of implementing the strategy is still valid. According to McKinsey, one of the world leaders in implementation consulting, up to $70 \%$ of program changes fail to achieve their goals, mainly due to employee resistance and lack of management support (Ewenstein, Smith, \& Sologar, 2015). The authors of the article point out the difficulties in researching this problem. In their opinion, some respondents were not entirely sure of their position in the hierarchical pyramid. Hierarchical items are not always well defined and explained at lower levels of the hierarchy. Also, they noticed that lower-level employees were frustrated when answering certain questions, which may have been due to a misunderstanding of the topic or a reluctance to express their views. Moreover, it shows that there is insufficient communication between the different levels of the hierarchy and that lower levels are usually not sufficiently familiar with the relevant facts in the implementation process, which, consequently, contributes to their sense of caution and fear of expressing their attitude.

The authors of the article: Is the Dominant Logic a Value or a Liability? On the Explorative Turn in the German Power Utility Industry, Ekaterina Brandtner 
and Jörg Freiling, see the need to continue research into the attributes of emotions of managers and management teams (Sundermeier, 2020). These factors play an important role in the case of exploratory turns related to the dominant logic. Research on the above-mentioned factors requires the use of specially selected research methods and appropriately prepared researchers. Contextual factors may also play a key role in the dominant logic in the process of strategic change. This study was about a large, traditional company. The situation is different for small businesses or start-ups. A contextual factor that also has a significant impact is the social and business situation related to the COVID-19 crisis.

Directions for further research were also indicated in the article by Jan Fazlagić, Aleksandra Szulczewska-Remi, and Windham Loopesko. According to the authors, further research must focus on the more specific aspects of youth policy, for example, how these policies are adapted to the needs of local economies and how they support the development of social capital in cities. Youth entrepreneurship should be seen as a broader social attitude, not just an economic activity. Youth involvement in entrepreneurial activities should not be strictly measured in terms of economic indicators. The experience and social capital gained during entrepreneurial activities constitute an added value for the city, regardless of its economic results. It seems that such aspects of youth entrepreneurship do not receive sufficient attention among researchers in this field. One limitation of the research process worth mentioning was the lack of visual, non-verbal cues that could facilitate contextualization during the interview. Although the survey for German participants was conducted in English, this may have had an impact on the quality of the research (the questions may have been misunderstood or misinterpreted by the German respondents). As mentioned earlier, Polish cities depend to a large extent on non-private financing, mainly from the EU. Innovation requires the involvement of resources, which in turn require funding. Therefore, the decision to invest in innovation depends on two critical factors, namely the initial incentive to allocate funds to innovation and the ability to obtain the necessary financial resources (Peneder, 2008).

\section{References}

Ansoff, H. J. (1965). Corporate Strategy. New York: McGraw-Hill.

Banaszyk, P., \& Urbanowska-Sojkin, E. (2007). Swoistość ewolucji zarządzania strategicznego przedsiębiorstwem. Współczesne Zarzq̨dzanie, 4, 29-39.

Barney, J. B. (1991). Firm resources and sustained competitive advantage. Journal of Management, 17(1), 99-120. http://dx.doi. org/10.1177/014920639101700108 
Block, J. H., Fisch, C. O., \& van Praag, M. (2017). The Schumpeterian entrepreneur: A review of the empirical evidence on the antecedents, behaviour and consequences of innovative entrepreneurship. Industry and Innovation, 24(1), 61-95. http://dx.doi.org/10.1080/13662716.201 6.1216397

Czakon, W. (2016). Network strategies logic. Problemy Zarzqdzania, 14/4(64), 17-30.

Domański, J. (2010). Zarzqdzanie Strategiczne Organizacjami Non-Profit w Polsce. Warszawa: Wolters Kluwer.

De Wit, B., \& Meyer, R. (2007). Synteza Strategii. Warszawa: Polskie Wydawnictwo Ekonomiczne.

Eisenhardt, K., \& Sull, D. N. (2001). Strategy as simple rules. Harvard Business Review, 79(1), 106-119.

Ewenstein, B., Smith, W., \& Sologar, A. (2015). Changing change management. Retrieved from https://www.mckinsey.com/featured-insights/ leadership/changing-change-management

Furmanek, W. (2018). Piąta rewolucja przemysłowa. Eksplikacja pojęcia. Edukacja - Technika - Informatyka, 24(2). http://dx.doi.org/10.15584/ eti.2018.2.38

Furrer, O., Thomas, H., \& Goussevskaia, A. (2007). The structure and evolution of the strategic management field: A content analysis of 26 years of strategic management research. International Journal of Management Reviews, 10(1), 1-23. http://dx.doi.org/10.1111/j.14682370.2007.00217.x

Grant, R.M. (2005). Contemporary Strategy Analysis. Chichester: John Wiley \& Sons Inc.

Gupta, A.K., Govindarajan, V., \& Wang, H. (2008). The Quest for Global Dominance: Transforming Global Presence into Global Competitive Advantage. San Francisco: Jossey-Bass.

Hermann, M., Boriss, O., \& Pentek, T. (2015). Design principles for Industrie 4.0 scenarios: A literature review. Retrieved from https://doi.org/10.13140/ RG.2.2.29269.22248

Hoskisson, R. E., Hitt, M. A, Wan, W. P., \& Yiu, D. (1999). Theory and research in strategic management: Swings of a pendulum. Journal of Management. 25(3), 417-456. http://dx.doi.org/10.1177/014920639902500307

Jelenc, L. (2007). Testing validity and reliability of classical and contemporary school of strategic management. International Journal of Education and Information Technologies, 3(1), 172-176.

Jelenc, L. (2009). Review of theories in strategic management field - toward the creation of schools of strategic management. The Business Review, 14(1), 240-247.

Kagermann, H., Wahlster, W., \& Helbig, J. (Eds.). (2013). Recommendations for Implementing the Strategic Initiative Industrie 4.0: Final Report of the Industrie 4.0 Working Group. Germany: Federal Ministry of Education and Research. 
Kaleta, A., \& Wittek-Crabb, A. (2016). Nowoczesny model zarządzania strategicznego - koncepcja badawcza. Prace Naukowe Uniwersytetu Ekonomicznego we Wrocławiu, 420, 129-140.

Kosch, O., \& Szarucki, M. (2020a). Transatlantic affiliations of scientific collaboration in strategic management: A quarter century of bibliometric evidence. Journal of Business Economics and Management, 3(21), 627646. https://doi.org/10.3846/jbem.2020.12395

Kosch, O., \& Szarucki, M., (2020b). An overview of 25 years of European scientific collaboration in the field of strategic management: A bibliometric analysis. European Management Review, 18(1), 51-69. http://dx.doi.org/10.1111/emre.12401

Krupski, R. (Ed.). (2010). Zarzqdzanie Strategiczne. Strategie Organizacji. Wałbrzych: Wałbrzyska Szkoła Zarządzania i Przedsiębiorczości.

Krzakiewicz, K., \& Cyfert, Sz. (2013). The network concept of strategic management and its limitations. Management, 17(1), 19-30. https://doi. org/10.2478/manment-2013-0002

Krzakiewicz, K., \& Cyfert, Sz. (2014). The strategic dimension of the dynamic capabilities of enterprises. Management, 18(2), 7-18. https://doi. org/10.2478/manment-2014-0038

McGrath, R. G. (2013). Transient advantage. Harvard Business Review, 91(6), 62-70.

Mintzberg, H., \& Waters, J.A., (1985). Of strategies, deliberate and emergent. Strategic Management Journal, 6(3), 257-272. http://dx.doi. org/10.1002/smj.4250060306

Obłój, K. (2007). Strategia Organizacji. Warszawa: Polskie Wydawnictwo Ekonomiczne.

Porter, M., (Ed.). (1986). Competition in Global Industries. Boston: Harvard Business School Press.

Okumus, F. (2003). A framework to implement strategies in organizations. Management Decision, 41(9), 871-882. http://dx.doi. org/10.1108/00251740310499555

Porter, M. (2001). Porter o Konkurencji. Warszawa: Polskie Towarzystwo Ekonomiczne.

Peneder, M. (2008). The problem of private under-investment in innovation: A policy mind map. Technovation, 28(8), 518-530. https://doi. org/10.1016/j.technovation.2008.02.006

Raynor, M. E. (2008). Paradoks Strategii. Warszawa: Studio Emka.

Roland Berger Strategy Consultants. (2011). Trend Compendium 2030. Retrieved from https://www.rolandberger.com/fr/Insights/GlobalTopics/Trend-Compendium/

Romanowska, M. (2004). Planowanie Strategiczne w Przedsiębiorstwie. Warszawa: Polskie Wydawnictwo Ekonomiczne.

Romanowska, M., \& Krupski, R. (2010). Rozwój i perspektywy nauki zarządzania strategicznego w Polsce. Przegląd badań i podstawowych 
publikacji. In A. Lachiewicz \& B. Nogalski (Eds.), Osiqggnięcia i Perspektywy Nauk o Zarzqdzaniu (pp. 201-231). Warszawa: Oficyna Wolters Kluwer.

Ronda-Pupo, G., \& Guerras-Martín, L. (2012). Dynamics of the evolution of the strategy concept 1962-2008: A co-word analysis. Strategic Management Journal, 33, 162-188. http://dx.doi.org/10.1002/smj.948

Schwab, K. (2016). The Fourth Industrial Revolution. New York: Crown Business.

Sanchez, R., \& Heene, A. (2004). The New Strategic Management. Organization. Competition and Competence. New York: John Wiley \& Sons.

Segal-Horn, S. (2004). The modern roots of strategic management. European Business Journal, 16(4), 133-142.

Simons, R. (2013). The entrepreneurial gap: How managers adjust span of accountability and span of control to implement business strategy. Harvard Business School Accounting \& Management Unit working Paper. https://dx.doi.org/10.2139/ssrn.2280355

Stabryła, A. (2000). Zarzqdzanie Strategiczne w Teorii i Praktyce Firmy. Warszawa: Wydawnictwo Naukowe PWN.

Sundermeier, J., Gersch, M., \& Freiling, J. (2020). Hubristic start-up founders - the neglected bright and inevitable dark manifestations of hubristic leadership in new venture creation processes. Journal of Management Studies, 57(5), 1037-1067. https://doi.org/10.1111/joms.12604.

Szczerski, T. (2012). Planowanie jako walka z niepewnością. In B. Glinka \& M. Kostera (Eds.), Nowe Kierunki w Organizacji i Zarzadzaniu (pp. 443-446). Warszawa: Oficyna Wolters Kluwer.

Taleb, N. (2007). The Black Swan: The Impact of the Highly Improbable. New York: Random House Publishing Group.

Taleb, N. (2012). Antifragile: Things That Gain from Disorder. New York: Random House Publishing Group.

Teece, D. (2007). Explicating dynamic capabilities: The nature and microfoudations of (sustainable) enterprise performance. Strategic Management Journal, 28(13), 1319-1350. http://dx.doi.org/10.1002/ smj.640

Walas, J. (2007). Kapitał intelektualny w kreowaniu wartości firmy. Zeszyty Naukowe Uniwersytetu Ekonomicznego w Krakowie, 753, 197-218.

Wąsowska, A. (2012). Współczesne koncepcje zarządzania strategicznego. In B. Glinka \& M. Kostera (Eds.), Nowe Kierunki w Organizacji i Zarzadzaniu (pp. 414-442). Warszawa: Oficyna Wolters Kluwer.

Vrdoljak-Raguž, I., Jelenc, L., \& Podrug, N. (2016). Neostrategic Management - An International Perspective on Trends and Challenges. Switzerland: Springer International Publishing.

Zakrzewska-Bielawska, A. (2017). Seeking the content of the relational strategy: Conceptual framework. International Journal of Management and Applied Science, 3(4), 67-74. 
Zakrzewska-Bielawska, A. (2021). Ambidextrous Strategy: Antecedents, Strategic Choices, and Performance. New York: Routledge.

\title{
Acknowledgment
}

The publication was co-financed by a subsidy awarded to the Cracow University of Economics.

\section{Biographical notes}

Tomasz Kafel is Associate Professor at the Cracow University of Economics, Department of Organization and Management Methods, the title of his postdoctoral dissertation/habilitation thesis is Methods of Professionalization in Non-Governmental Organisations. His research interests focus on methodology of organization and management, strategic management, nongovernmental organizations management, and creative thinking methods. $\mathrm{He}$ is the author and co-author of over 120 scientific publications in the form of monographs, articles, and conference materials.

Bernard Ziębicki is Associate Professor at the Cracow University of Economics, head of the Department of Organization and Management Methods, thematic editor in the field of management in the scientific journals: "Organizational and Management" and "Cracow Review Economics and Management", author and co-author of over 180 scientific publications in the form of monographs, articles and conference materials on the following issues: organization and management methods, new management concepts, organizational effectiveness, and information management.

\begin{abstract}
Abstrakt
Cel: Zarzqdzanie strategiczne rozwijane jest $w$ teorii oraz praktyce biznesowej od ponad 50 lat. Współczesne uwarunkowania funkcjonowania przedsiębiorstw tworza nowe wyzwania dla zarzqqdzania strategicznego. Należq do nich m.in. wykorzystanie zdolności dynamicznych w budowaniu strategii, strategie relacyjne, sieciowość organizacji, rozwój technologii i automatyzacja procesów, strategie globalne. Wyzwania te często określane sq mianem zarzqdzania neostrategicznego. Celem niniejszej publikacji jest przedstawienie wyników badań dotyczqcych nowych koncepcji i wyzwań zarzqdzania strategicznego. Metodyka: Głównq metodq badawczq tego artykułu był narracyjny przeglad literatury. Na podstawie przeprowadzonego badania scharakteryzowano rozwój koncepcji oraz współczesne trendy i wyzwania w zakresie zarzqdzania strategicznego. Dokonano także syntezy problemów i wyników badań przedstawianych $w$ artykułach zamieszczonych $w$ tym wydaniu specjalnym JEMI. Wyniki: Powstało wiele różnorodnych szkół oraz podejść do formułowania strategii. Wskazujq one różne czynniki, umożliwiajqqce osiqgnnięcie sukcesu w zarzq̨dzaniu strategicz-
\end{abstract}


nym, takie jak: wyznaczanie długofalowych celów, dobór programów oraz planów ich realizacji (szkoła planistyczna); połqczenie przedsiębiorstwa z otoczeniem (szkoła ewolucyjna); koncentrowanie uwagi na przewadze konkurencyjnej i osiaganych wynikach (szkoła pozycyjna), bazowanie na własnych zasobach i kompetencjach (szkoła zasobowa), wykorzystanie szans i kreowanie innowacji (szkoła prostych regut); wybór najlepszej opcji i orientacji w zarzqdzaniu przedsiębiorstwem (szkoła realnych opcji); czy też eklektyczne ujęcia, integrujq̨ce wymienione podejścia. Rozwój koncepcji zarzqdzania strategicznego postępuje nadal. Realizowany jest on dwuwymiarowo. Pierwszy ze wspominanych wymiarów zwiqzany jest z pojawianiem się kolejnych, nowych koncepcji zarzq̨dzania strategicznego, które często nawiq̨zujq do wcześniejszych szkół i podejść. Drugi wymiar rozwoju dotyczy operacjonalizacji i dostosowania dotychczasowych koncepcji do zmieniających się warunków. Implikacje dla teorii i praktyki: W opracowaniu scharakteryzowano wyniki badań przedstawione w artykułach zamieszonych w tym numerze JEMI. Dotyczq one różnych problemów i wyzwań w zakresie zarzq̨dzania strategicznego, jak: zwiq̨zek między dynamikq rynku, orientacjq rynkowq i wynikami przedsiębiorstw; innowacyjność firm jako współczesna orientacja strategiczna firm; wdrażanie strategii i zarzqdzanie zmianq organizacyjnq; problemy strategicznego zarzqdzania rozwojem miasta. Oryginalność $i$ wartość: Przedstawione w opracowaniu problemy dotyczq wyzwań oraz nowych koncepcji w zarzqdzaniu strategicznym. Wzbogacaja dotychczasowq wiedzę na temat rozwoju zarzqdzania strategicznego, a także tworzq inspiracje dla kolejnych badaczy i praktyków zarzqdzania. Słowa kluczowe: ewolucja koncepcji zarzq̨dzania strategicznego, zarzq̨dzanie neostrategiczne, sukces wdrażania strategii, dynamika rynku, zarzqqdzanie strategiczne miastami, strategia innowacji

\section{Conflicts of interest}

The authors declare no conflict of interest.

\section{Citation}

Kafel, T., \& Ziębicki, B. (2021). Dynamics of the evolution of the strategic management concept: From the planning school to the neostrategic approach. Journal of Entrepreneurship, Management and Innovation, 17(2), 7-28. https://doi.org/10.7341/20211721 